\title{
Front Matter: Volume 9182
}

, "Front Matter: Volume 9182," Proc. SPIE 9182, Liquid Crystals XVIII, 918201 (10 November 2014); doi: 10.1117/12.2176710

Event: SPIE Organic Photonics + Electronics, 2014, San Diego, California, United States 


\section{PROCEEDINGS OF SPIE}

\section{Liquid Crystals XVIII}

Iam Choon Khoo

Editor

17-20 August 2014

San Diego, California, United States

Sponsored and Published by

SPIE 
The papers included in this volume were part of the technical conference cited on the cover and title page. Papers were selected and subject to review by the editors and conference program committee. Some conference presentations may not be available for publication. The papers published in these proceedings reflect the work and thoughts of the authors and are published herein as submitted. The publisher is not responsible for the validity of the information or for any outcomes resulting from reliance thereon.

Please use the following format to cite material from this book:

Author(s), "Title of Paper," in Liquid Crystals XVIII, edited by lam Choon Khoo, Proceedings of SPIE Vol. 9182 (SPIE, Bellingham, WA, 2014) Article CID Number.

ISSN: 0277-786X

ISBN: 9781628412093

Published by

SPIE

P.O. Box 10, Bellingham, Washington 98227-0010 USA

Telephone +1 3606763290 (Pacific Time) · Fax +1 3606471445

SPIE.org

Copyright $@ 2014$, Society of Photo-Optical Instrumentation Engineers.

Copying of material in this book for internal or personal use, or for the internal or personal use of specific clients, beyond the fair use provisions granted by the U.S. Copyright Law is authorized by SPIE subject to payment of copying fees. The Transactional Reporting Service base fee for this volume is $\$ 18.00$ per article (or portion thereof), which should be paid directly to the Copyright Clearance Center (CCC), 222 Rosewood Drive, Danvers, MA 01923. Payment may also be made electronically through $\mathrm{CCC}$ Online at copyright.com. Other copying for republication, resale, advertising or promotion, or any form of systematic or multiple reproduction of any material in this book is prohibited except with permission in writing from the publisher. The CCC fee code is 0277-786X/14/\$18.00.

Printed in the United States of America.

Publication of record for individual papers is online in the SPIE Digital Library.

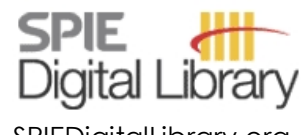

SPIEDigitalLibrary.org

Paper Numbering: Proceedings of SPIE follow an e-First publication model, with papers published first online and then in print and on CD-ROM. Papers are published as they are submitted and meet publication criteria. A unique, consistent, permanent citation identifier (CID) number is assigned to each article at the time of the first publication. Utilization of CIDs allows articles to be fully citable as soon as they are published online, and connects the same identifier to all online, print, and electronic versions of the publication. SPIE uses a six-digit CID article numbering system in which:

- The first four digits correspond to the SPIE volume number.

- The last two digits indicate publication order within the volume using a Base 36 numbering

system employing both numerals and letters. These two-number sets start with 00, 01, 02, 03, 04,

$05,06,07,08,09,0 A, 0 B \ldots$. OZ, followed by 10-1Z, 20-2Z, etc.

The CID Number appears on each page of the manuscript. The complete citation is used on the first page, and an abbreviated version on subsequent pages. Numbers in the index correspond to the last two digits of the six-digit CID Number. 


\title{
Contents
}

\author{
vii Authors \\ ix Conference Committee \\ xi Direct electronic probing of biological complexes formation (Organic Photonics + \\ Electronics Plenary Paper [9183-402]) \\ xxi Real-time holographic display using doped liquid crystals (Invited Paper Summary \\ [9182-34])
}

\section{SESSION $1 \quad$ LC PHOTONICS}

918203 Vertical-cavity surface-emitting laser with liquid crystal external cavity [9182-2]

918204 Light-induced effects in dye-doped liquid crystals: role of space charges (Invited Paper) [9182-3]

918206 Synthesis, liquid-crystalline behavior, and photoluminescence properties of novel $\mathrm{Au}(\mathrm{I})$ complex with naphthalene ring in a mesogenic core (Invited Paper) [9182-5]

\section{SESSION 2 NOVEL LC MATERIALS AND PHOTONICS}

918207 Light-emitting liquid-crystal displays constructed from AlE luminogens (Keynote Paper) [9182-6]

918208 Fast algorithms for liquid crystal modelling (Invited Paper) [9182-7]

918209 Molecular dynamics in azobenzene liquid crystal polymer films studied by transient grating technique (Invited Paper) [9182-8]

$91820 \mathrm{~A}$ Mechanoresponsive change in photoluminescent color of rod-like liquid-crystalline compounds and control of molecular orientation on photoaligned layer (Invited Paper) [9182-9]

$9182 \mathrm{OB} \quad$ Large aperture and polarizer-free liquid crystal lenses for ophthalmic applications [9182-36]

\section{SESSION 3 PHOTONICS AND COMPLEX PHENOMENA}

$91820 \mathrm{C}$ Imaging and visualization of complex nematic fields (Keynote Paper) [9182-11] 
9182 Ol Ultrahigh sensitivity in liquid-crystal-based immunodetection by surface modification of the alignment layer (Invited Paper) [9182-16]

$9182 \mathrm{OJ}$ Contact-angle measurements as a means of probing the surface alignment characteristics of liquid crystal materials on photoalignment layers (Invited Paper) [9182-17]

$9182 \mathrm{OL} \quad$ Investigation of host liquid crystal composition on polymer stabilised blue phase properties (Invited Paper) [9182-19]

\section{SESSION 5 NOVEL LC MATERIALS II}

9182 OP Electrooptics of chiral nematics formed by molecular dimers (Invited Paper) [9182-24]

$91820 Q \quad$ New twist on the helical nanofilament phase of bent-core liquid crystals (Invited Paper) [9182-25]

9182 OR Tailored liquid crystal devices for specific imaging applications (Invited Paper) [9182-26]

9182 OS Infrared reflector based on liquid crystal polymers and its impact on thermal comfort conditions in buildings [9182-27]

SESSION 6 SWITCHES, FILTERS, CONTROL, DISPLAY

9182 OU Transient responses of liquid crystals for optical switching with microseconds: nanoseconds response speed [9182-29]

9182 OW Liquid crystal claddings for passive temperature stabilization of silicon photonics [9182-31]

SESSION $7 \quad$ LASER, DISPLAY, AND TUNABLE OPTICS

9182 OY Lasing and waveguiding in smectic A liquid crystal optical fibers (Keynote Paper) [9182-33]

SESSION 8 PHOTOVOLTAIC AND NOVEL LC

918214 Photoinduced deformation of liquid crystal polymers (Invited Paper) [9182-39]

POSTER SESSION

918218 Photonic density of states of a stack of cholesteric liquid crystals and isotropic medium layers [9182-44]

iv 
918219 Dependence of the electrooptical properties of polymer-dispersed vertical aligned liquid crystals on the surface affinity of the liquid crystal and monomer [9182-45]

$91821 \mathrm{~A}$ Effect of UV curing conditions on polymerized tunable chiral nematic liquid crystals [9182-46]

9182 1B On a photonic density of states of cholesteric liquid crystal cells [9182-47]

9182 IG Fast response wavelength tunable filter using Vertically-Aligned Polymer-Stabilized Liquid Crystals (VA-PSLC) with a curing voltage [9182-52] 
Proc. of SPIE Vol. $9182918201-6$

Downloaded From: https://www.spiedigitallibrary.org/conference-proceedings-of-spie on 26 Apr 2023 Terms of Use: https://www.spiedigitallibrary.org/terms-of-use 
Vitek, Maruša, OY

Wang, YU-Jen, OB

Xiang, Jie, OP

Xie, Y., 03

Yamada, Shigeyuki, 06

Yamana, Itaru, OL

Yoon, Tae-Hoon, 19

Yu, Yanlei, 14

Zhang, C., OQ

Zhao, Dongyu, 07

Zhao, S., OU

Žumer, Slobodan, OC

Proc. of SPIE Vol. 9182 918201-8

Downloaded From: https://www.spiedigitallibrary.org/conference-proceedings-of-spie on 26 Apr 2023 Terms of Use: https://www.spiedigitallibrary.org/terms-of-use 


\title{
Conference Committee
}

\author{
Symposium Chair
}

Zakya H. Kafafi, National Science Foundation, ret (United States)

Conference Chair

Iam Choon Khoo, The Pennsylvania State University (United States)

Conference Program Committee

Timothy J. Bunning, Air Force Research Laboratory (United States)

Shaw-Horng Chen, University of Rochester (United States)

Neil Collings, University of Cambridge (United Kingdom)

Jean-Pierre Huignard, Jphopto (France)

Tomiki Ikeda, Chuo University (Japan)

Oleg D. Lavrentovich, Kent State University (United States)

Francesco Simoni, Università Politecnica delle Marche (Italy)

David M. Walba, University of Colorado at Boulder (United States)

\section{Session Chairs}

1 LC Photonics

Iam Choon Khoo, The Pennsylvania State University (United States)

2 Novel LC Materials and Photonics

Timothy J. White, Air Force Research Laboratory (United States)

3 Photonics and Complex Phenomena

Oleg D. Lavrentovich, Kent State University (United States)

4 Novel LC Materials I

David M. Walba, University of Colorado at Boulder (United States)

5 Novel LC Materials II

Kenneth L. Marshall, University of Rochester (United States)

6 Switches, Filters, Control, Display

Francesco Simoni, Università Politecnica delle Marche (Italy) 
$7 \quad$ Laser, Display, and Tunable Optics

Kenneth L. Marshall, University of Rochester (United States)

8 Photovoltaic and Novel LC

Iam Choon Khoo, The Pennsylvania State University (United States)

Proc. of SPIE Vol. $9182918201-10$

Downloaded From: https://www.spiedigitallibrary.org/conference-proceedings-of-spie on 26 Apr 2023 Terms of Use: https://www.spiedigitallibrary.org/terms-of-use 